\title{
Analisis Break Even Point Usaha Peternakan Sapi Perah di Kabupaten Semarang
}

Ruth Dameria Halohoa, Mochamad Sugiartob

aProgram Studi Agribisnis Fakultas Sains dan Teknologi Universitas Quality Berastagi email : ruthdameria28@gmail.com ${ }^{b}$ Fakultas Peternakan Universitas Jenderal Soedirman

\section{Article Info}

Article history:

Received 05 March 2021

Received in revised from 06 March 2021 Accepted 26 April 2021

DOI:

https://doi.org/10.32938/ag.v6i2.1323

Keywords:

BEP

Maintenance

Smallholders farmers

Dairy Cattle

\begin{abstract}
Abstrak
This research analyzes the Break-Even Point of smallholder dairy Farming and to know the maintenance of dairy cattle in Semarang Regency. A survey method was used in this research. The sampling technique in this study used the Multistage Random Sampling Method. Respondents studied were 80 dairy farmers. The data obtained were analyzed descriptively and quantitatively. The result showed BEP in Semarang regency based on revenue of IDR 31,916/day and based on the amount of production of 10.57 liters/day. The average revenue volume of production/ day is 24.88 Liters/day and the average revenue is IDR 70,771 /day thus the dairy business is already operating above the BreakEven Point. The maintenance of dairy cows consists of feeding (forage and concentrate) and drinking adlibitum, livestock sanitation is carried out twice a day, 12 months of calving interval, the type of pen is conventional and milking is done twice a day, namely in the morning and evening.
\end{abstract}

\section{Pendahuluan}

Permintaan susu yang semakin meningkat merupakan peluang untuk perkembangan usaha peternakan sapi perah. Selama ini kebutuhan komsumsi susu masih diimport sebesar $68 \%$. Indonesia hanya mampu memenuhi sebanyak 32\%. Masyarakat semakin menyadari kebutuhan akan gizi terhadap protein hewani sehingga mengakibatkan peningkatankomsumsi susu dari tahun ketahun (Londa et al.,2017). Kabupaten Semarang merupakan penghasil susu nomor dua terbesar di Jawa Tengah. Jumlah produksi susu terbesar pertama adalah kabuipaten Boyolali sebesar 49.716.000 Liter/Tahun dan Kabupaten Semarang merupakan penghasil susu nomor dua sebesar 28.029.000 Liter/Tahun. Populasi sapi perah di Kabupaten Semarang sebesar 25.780 ekor. Populasi sapi perah merupakan nomor dua terbesar di Jawa tengah. (Dinas Peternakan dan Kesehatan Hewan Provinsi Jawa Tengah, 2020). Berdasarkan data bahwa populasi sapi perah yang tinggi berpengaruh terhadap jumlah produksi susu. Produksi susu sapi perah yang tinggi di Kabupaten Semarang merupakan potensi untuk pengembangan usaha peternakan agar dapat memenuhi kebutuhan akan permintaan susu.

Peternakan yang ada di Kabupaten Semarang masih bersifat tradisional dan merupakan usaha sambilan (Haloho et al., 2013). Tujuan utama dari suatu peternakan adalah memperoleh keuntungan yang tinggi. Oleh karena itu diperlukan analisis pendapatan untuk mengetahuinya. Peternak sapi perah belum melakukan analisis pendapatan dengan baik, selama ini hanya dilakukan perhitungan pendapatan kotor yaitu hasil penjualan susu sapi perah tanpa memperhatikan biaya produksi lain yaitu penyusutan peralatan, kandang dan tenaga kerja sehingga peternak tidak mengetahui untung maupun rugi (Ermawan, 2016).

Masalah yang sering timbul dalam usaha peternakan belum memahami sepenuhnya caracara untuk mengetahui keuntungan dan analisis usaha yang menyebabkan usaha kurang berkembang. Maka dari itu perlu dilakukan suatu analisis usaha untuk menghitung BEP (Haloho, 2020). Break Even Point adalah analisa untuk mengetahui kaitan biaya tetap, variabel, volume kegiatan dan penjualan. BEP diperlukan agar mengetahui suatu usaha tidak menderita keuntungan ataupun kerugian.

\section{Metode}

Metode survei adalah metode yang digunakan dalam penelitian dengan bantuan kuesioner. Penelitian berlokasi di Kabupaten Semarang. Lokasi penelitian adalah di Kecamatan Getasan dan Ungaran Barat dipilih dengan pertimbangan bahwa daerah tersebut memiliki jumlah populasi sapi perah yang tinggi. Jumlah populasi sapi perah di Kabupaten Semarang adalah 25.780 ekor. Jumlah responden sebanyak 80 peternak sapi perah secara acak dipilih. Analisis data adalah sebagai berikut (Soekardono, 2009):

1) Analisis Pendapatan

$\Pi=\mathrm{TR}-\mathrm{TC}$

$\Pi=$ Keuntungan usaha sapi perah

$\mathrm{TR}=$ Total Revenue

$\mathrm{TC}=$ Total Cost 


\section{2) Analisa Break Even Point}

Analisis untuk mengetahui sebuah usaha mengalami keuntungan maupun kerugian adalah BEP. Analisis BEP sebagai berikut

$$
\begin{aligned}
& \text { BEP dalam unit }\left(\mathrm{Q}_{\mathrm{BEP}}\right)=\frac{\text { Total Biaya Tetap }}{(\text { Harga Jual per Unit - Biaya Variabel per Unit })} \\
& \text { BEP dalam rupiah }\left(\mathrm{Q}_{\text {sales }}\right)=\frac{\text { Total Biaya Tetap }}{\left(1-\frac{\text { Total Biaya Variabel }}{\text { Volume Penjualan }}\right)} \ldots \ldots \ldots \ldots \ldots \ldots \ldots \ldots \ldots \ldots \ldots \ldots \ldots \ldots \ldots \ldots
\end{aligned}
$$

\section{Hasil dan Pembahasan}

Analisis Pendapatan Usaha Peternakan Sapi Perah di Kabupaten Semarang Analisis Usaha

Penerimaan peternakan meliputi hasil jual susu, penjualan pedet, penjualan sapi afkir dan penjualan pejantan. Jumlah penerimaan yaitu Rp 30.245.200/tahun atau Rp 11.632.769 ST/ Tahun. Penjualan susu merupakan penerimaan terbesar sebesar Rp 25.612.700,- (84,68\%); penjualan pedet sebesar Rp 2.613.250,- (8,69\%); penjualan pejantan sebesar Rp 1.112.500,$(3,74 \%)$ dan penjualan sapi afkir sebesar Rp 878.750,- (2,9\%). Penjualan susu sapi perah merupakan penerimaan terbesar dari usaha peternakan sapi perah (Haloho, 2018). Jumlah penerimaan peternak tergantung pada harga dan jumlah produk yang dijual. Sumber penerimaan utama pada usaha peternakan sapi perah laktasi adalah penjualan susu (Ernawan et al., 2016). Susu merupakan Santosa et al., (2013) menyatakan penerimaan usaha ternak sapi perah rakyat di Kabupaten Boyolali terdiri dari penjualan susu, sapi afkir dan pedet sebesar Rp. 13.443.918,27.

Tabel 1. Jumlah Penerimaan Peternakan Sapi Perah di Kabupaten Semarang

\begin{tabular}{llll}
\hline No & Keterangan & Jumlah (Rp/ Tahun) & Persentase (\%) \\
\hline 1 & Jual susu & 25.612 .700 & 84,68 \\
2 & Penjualan pedet & 2.631 .250 & 8,69 \\
3 & Penjualan sapi afkir & 878.750 & 2,90 \\
4 & Penjualan Pejantan & 1.122 .500 & 3,74 \\
\hline & Jumlah & 30.245 .200 & 100 \\
\hline
\end{tabular}

Sumber : Data Primer ;Diolah 2021

\section{Biaya Usaha Ternak}

Susu adalah hasil produksi yang utama dari usaha peternakan sapi perah. Pemeliharaan sapi perah, biaya yang dikeluarkan meliputi biaya Tetap dan biaya tidak tetap yang digunakan meliputi biaya cash dan non cash. Biaya tetap adalah biaya yang tidak mengalami perubahan walaupun terjadi perubahan pada volume produksi atau penjualan. Biaya tetap non cash meliputi depresiasi kandang, depresiasi ternak dan depresiasi alat. Biaya tidak tetap (variabel) yang digunakan meliputi cash dan non cash. Biaya variabel cash yang dikeluarkan meliputi biaya pakan konsenterat, biaya obat-obatan dan biaya listrik. Biaya variabel cash meliputi biaya hijauan dan tenaga kerja.

Jumlah biaya cash peternak sebesar Rp 12.801.175/Tahun atau Rp 1.066.764,/bulan dan biaya yang diperhitungkan (noncash) sebesar Rp 8.372.051/tahun atau Rp 699.670,- /bulan. Jumlah biaya usaha yang dikeluarkan sebesar Rp 21.161.120/tahun dan 1.723.426/Bulan. Biaya usaha peternakan berasal dari biaya tunai ( cash) sebesar 60,43\% dan biaya yang diperhitungkan (non cash) sebesar 60,43\% dan biaya yang diperhitungkan (non cash) sebesar $39,57 \%$.

Jumlah biaya tetap yang dikeluarkan sebesar Rp 2.247.631,-/tahun meliputi biaya depresiasi kandang sebesar Rp 313.314, depresiasi ternak senilai Rp 1.911.607 serta depresiasi alat senilai Rp 26.816 (Tabel 2). Jumlah biaya tidak tetap sebesarRp 18.921.489. Biaya tidak tetap dibagi dua yaitu biaya cash dan non cash Biaya tetap cash terdiri dari biaya pakan konsenterat sebesar Rp 12.605.813,- ( 59,91\%); biaya IB sebesar Rp 125.437,- $(12,46 \%)$ dan biaya obat-obatan sebesar Rp 69.925 ( 0,33\%). Biaya tetap non cash terdiri dari biaya hijauan sebesar Rp Rp 3.402.369,- ( 16,06\%); Biaya tenaga kerja sebesar Rp 2.638.071,- (0,6\%) dan biaya listrik sebesar Rp 79.875,- $(0,37)$. Berdasarkan biaya usaha ternak yang merupakan biaya terbesar yaitu biaya pakan. Biaya pakan terdiri dari biaya pakan konsenterat dan biaya pakan hijauan sebesar Rp 16.008.181/tahun $(75,57 \%)$ dari jumlah biaya usaha ternak. Hasil Penelitian 
Haloho (2018) dalam usaha peternakan sapi perah pakan merupakan biaya produksi terbesar. Karena pakan merupakan salah satu kebutuhan pokok sapi perah selain untuk perkembangan dan pertumbuhan serta produksi susu.

Biaya pakan yang terdiri dari biaya pakan hijauan dan konsentrat merupakan biaya terbesar dalam usaha peternakan (Haloho, 2020). Dijelaskan lebih lanjut Londa et al., (2013) pakan merupakan komponen biaya tertinggi dari jumlah biaya produksi. Peningkatan pakan konsenterat akan meningkatkan jumlah produksi susu, petani menggunakan konsenterat sebagai ransum untuk meningkatkan produksi susu (Haloho et al., 2018)

Tabel 2. Biaya Usaha Ternak Sapi Perah di Kabupaten Semarang

\begin{tabular}{|c|c|c|c|c|c|}
\hline \multirow[t]{2}{*}{ No } & \multirow[t]{2}{*}{ Keterangan } & \multicolumn{2}{|c|}{ Biaya Produksi (Rp/Tahun) } & \multirow[t]{2}{*}{ Total Biaya } & \multirow[t]{2}{*}{ Persentase } \\
\hline & & Cash & Non Cash & & \\
\hline & Biaya Tetap & & & & \\
\hline 1 & Depresiasi Kandang & & 313.314 & 313.314 & 9,02 \\
\hline 2 & Depresiasi Ternak & & 1.911 .607 & 1.911 .607 & 1,46 \\
\hline \multirow[t]{3}{*}{3} & Depresiasi Alat & & 26.816 & 26.816 & 0,17 \\
\hline & Total Biaya Tetap & & 2.251 .737 & 2.251 .737 & 10,67 \\
\hline & Biaya Tidak Tetap & & & & \\
\hline 1 & Biaya Hijauan & & 3.402 .369 & 3.402 .369 & 16,06 \\
\hline 2 & Biaya Konsentrat & 12.605 .813 & & 12.605 .813 & 59,51 \\
\hline 3 & Obat-obatan & 69.925 & & 69.925 & 0,33 \\
\hline 4 & Tenaga Kerja & & 2.638 .071 & 2.638 .071 & 0,6 \\
\hline 5 & IB & 125.437 & & 125.437 & 12,46 \\
\hline \multirow[t]{3}{*}{6} & Listrik & & 79.875 & 79.875 & 0,37 \\
\hline & $\begin{array}{ll}\text { Total } & \text { Biaya } \\
\text { tetap } & \\
\end{array}$ & Tidak 12.801.175 & 6.120 .314 & 18.921 .489 & 89,33 \\
\hline & Total Biaya & 12.801 .175 & 8.372 .051 & 21.173.226 & 100 \\
\hline
\end{tabular}

Sumber: Data Primer diolah 2021

\section{Keuntungan Usaha}

Keuntungan adalah hasil dari penerimaan dikurangi dengan biaya tetap dan tidak tetap yang meliputi jumlah biaya (non cash) mupun tunai (Anindyasari et al.,2019). Total penerimaan sebesar Rp 30.245.200,-/tahun dan total biaya produksi sebesar Rp 21.173.226,-/tahun. Keuntungan yang diperoleh sebesar Rp 9.071.974,-/ Tahun atau Rp 755.997,-/bula ( Tabel 3).

Tabel 3. Keuntungan Usaha Peternakan Sapi Perah di Kabupaten Semarang

\begin{tabular}{lll}
\hline No & Keterangan & Jumlah $(\mathrm{Rp})$ \\
\hline 1. & Penerimaan & 30.245 .200 \\
2 & Biaya Produksi & 21.173 .226 \\
3 & Keuntungan & 9.071 .974 \\
\hline
\end{tabular}

Sumber: Data Primer; Diolah 2021

\section{Analisis BEP}

BEP digunakan menilai apakah sebuah usaha tidak mengalami rugi maupun untung atau dikenal dengan nama titik impas (Emmawati, 2007). Berdasarkan Tabel 4 analisis Break even Point berdasarkan penerimaan adalah Rp 31.916/hari dan berdasarkan jumlah produksi sebesar 10,57 Liter/hari. Rata-rata jumlah penerimaan usaha peternakan sapi perah adalah Rp 70.77 /hari dengan rata-rata jumlah produksi adalah 24,88 liter/hari. Berdasarkan hasil tersebut, usaha peternakan sapi perah sudah beroperasi diatas BEP.

Tabel 4. Break Even Point Usaha Sapi Perah Peternakan Rakyat Kabupaten Semarang

\begin{tabular}{lll}
\hline No & Keterangan & Jumlah \\
\hline 1 & Biaya Tetap & Rp 6.169 \\
2 & Biaya Variabel & $R p ~ 16.767$ \\
3 & Penjualan & Rp 70.771 \\
4 & Produksi Susu (liter) & 24,88 \\
\hline 5 & BEP (Rupiah) & Rp 31.916 \\
\hline 6 & BEP (Liter) & 10,57 \\
\hline
\end{tabular}




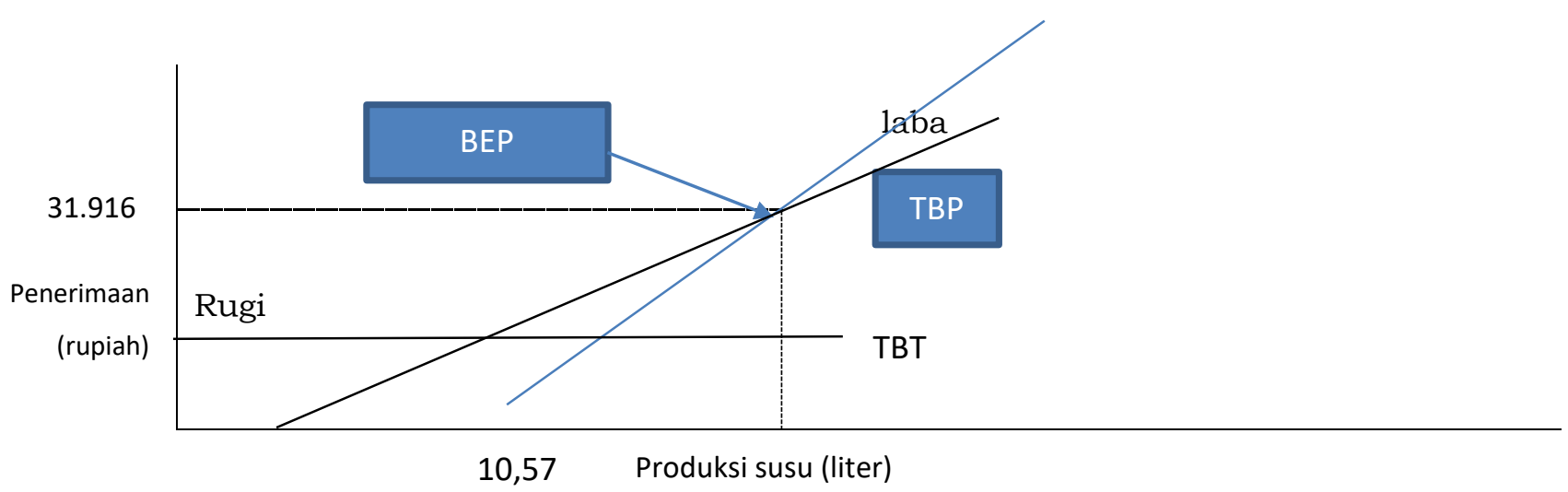

Gambar 1 : Break Even Point Usaha Peternakan Sapi Perah Rakyat Kabupaten Semarang

Keterangan :

TP $=$ Total Penerimaan

TBT $=$ Total biaya tetap

TBP $=$ Total Biaya Produksi

\section{Pemeliharaan Sapi Perah di Kabupaten Semarang Pakan dan Minum}

Pakan sapi perah menjadi faktor utama yang dapat mempengaruhi produksi dan kualitas susu, serta dapat mempengaruhi kesehatan sapi. Pakan yang diberikan peternak pada umumnya terdiri dari hijauan berupa rumput gajah segar dan rumput lapangan dan konsentrat jadi dan ditambahkan pakan tambahan yang terdiri dari ampas tahu, bekatul, onggok dan ubi kayu. Pakan sapi perah adalah rumput dan konsentrat (pakan penguat) dan pemberiannya harus disesuaikan dengan bobot badan, status produksi, dan status kesehatan sapi (Sudono et al., 2003). Dijelaskan lebih lanjut oleh Anggaraeni dan Mariana (2016) bahwa umumnya ternak sapi perah diberikan pakan hijauan dan konsenterat. Sistem pemberian pakan yang dilakukan pada umumnya dua kali yaitu pagi dan sore hari. Pakan hijauan segar diberikan dua kali yaitu pagi dan sore hari setelah pemerahan. Konsenterat diberikan sebelum sapi diperah. Simamora et al.,(2015) menyatakan bahwa Pemberian pakan konsenterat sebagai pakan tambahan sangat mempengaruhi produktivitas susu sapi, pemberian pakan konsenterat adalah sebelum sapi diperah. Pemberian air minum dilakukan secara ad libitum.

\section{Pencegahan Penyakit}

Pencegahan penyakit yang dilakukan oleh peternak pada umumnya adalah dengan pemberian obat, vitamin, dan vaksinasi terhadap ternaknya serta sanitasi kandang dan sanitasi peralatan setiap hari. Sanitasi kandang dilakukan sebelum melakukan pemerahan yaitu membersihkan kandang dari kotoran-kotoran yang berasal dari feses sapi maupun dari sisa pakan. Sanitasi peralatan yaitu membersihkan semua peralatan menggunakan air sampai bersih, seperti mencuci milkcan yang telah digunakan untuk menampung susu selama pemerahan dan mencuci ember yang digunakan untuk menampung susu yang telah disaring. Tujuannya agar mikroorganisme tidak dapat berkembangbiak di dalam milkcan maupun ember yang berasal dari sisa susu yang tidak dibersihkan. Simamora et al.,(2015) menyatakan bahwa peternak membersihkan sapi dua kali sehari sebelum dilakukan pemerahan. Kebersihan sapi sangat penting untuk menjaga kesehatan ternak dan kebersihan susu.

Pemeliharaan kesehatan ternak dilakukan dengan pemberian obat-obatan secara rutin setiap enam bulan sekali dan vaksin dari dinas peternakan dan perikanan Kabupaten Semarang setiap satu tahun sekali. Jenis obat-obatan yang diberikan yaitu obat cacing (wormzol), antibloat dan B Complex sedangkan jenis vaksin yang umumnya diberikan yaitu vaksin Brucell. Penyakit tersebut dapat mengakibatkan keguguran pada ternak, kematian induk dan berpengaruh kurang baik terhadap kontinuitas produksi susu. Secara umum penyakit yang dijumpai yaitu mencret dan kembung. Pemeriksaan kesehatan dari peternak dapat mengurangi munculnya penyakit tersebut. Anggraeni dan Mariana (2016) menyatakan bahwa kesehatan ternak merupakan aspek yang sangat penting dalam usaha budidaya ternak. Ternak yang sehat akan menghasilkan produktivitas yang optimal. Peternak perlu memperhatikan kebersiha kandang, pemberian obat cacing secara berkala dan pemberian vitamin perlu ditingkatkan. 


\section{Reproduksi Sapi Perah}

Pengelolaan reproduksi merupakan faktor yang penting karena untuk mengetahui apakah sapi betina dapat beranak setiap tahunnya. Perkawinan ternak dilokasi penelitian dilakukan dengan menggunakan cara Inseminasi Buatan (IB) yang teknisnya dibantu oleh petugas IB dari Dinas Peternakan. Peternak tidak perlu membeli straw IB, melainkan cukup memberikan uang transportasi kepada petugas IB antara Rp 30.000,- sampai Rp 35.000,- /IB. Peternak yang memiliki sapi dara biasanya mengawinkan sapinya pertama kali saat umur 18-21 bulan sehingga dapat mencapai laktasi pertama pada umur 27-30 bulan. Setelah sapi melahirkan nantinya akan dikawinkan kembali membutuhkan waktu sekitar 2 atau 3 bulan. Sapi yang berhasil dikawinkan nantinya akan bunting, dan saat umur 7 bulan sapi diistirahatkan untuk tidak diperah hal ini dikarenakan untuk persiapan kelahiran berikutnya. Perkawinan ternak yang dilakukan untuk ternak sapi perah adalah dengan cara inseminasi buatan (Anggraeni dan Mariana, 2016).

Jarak beranak antara kelahiran pertama dengan kelahiran anak berikutnya (Calving internal) membutuhkan waktu sekitar 12 bulan. Calving interval dapat bertambah dikarenakan sapi yang dikawinkan selalu gagal untuk bunting, jadi tidak sesuai dengan harapan dari peternak. Hertanto et al., (2012) menyatakan bahwa perbaikan selang beranak atau calving interval untuk sapi perah adalah 12 dan 13 bulan mampu memperbaiki profitabilitas usaha pada peternakan sapi perah rakyat.

\section{Perkandangan}

Kandang merupakan salah satu sarana yang sangat penting dalam menentukan keberhasilan usaha ternak sapi perah. Kandang sebagai tempat tinggal sapi harus memberikan perlindungan bagi sapi perah dari segala aspek yang mengganggu. Bangunan kandang umumnya merupakan bangunan permanen mulai dari yang sederhana sampai dengan penggunaan konstruksi beton. Dinding terbuat dari batu-bata/tembok, tempat pakan dan minum sudah permanen dan lantai terbuat dari semen. Lantai kandang terbuat dari semen sehingga tidak licin serta dibuat agak miring agar mudah dibersihkan selain itu atap kandang terbuat dari genting.

Tipe kandang yang digunakan pada umumnya merupakan tipe konvesional dua baris. Tipe kandang ini menempatkan sapi perah pada satu jajaran yang dibatasi oleh penyekat dan sapi ditempatkan dalam dua baris saling bertolak belakang yang dibuatkan jalur untuk jalan ditengahnya. Menurut Sunarto (2007) bahwa kandang konvesional adalah kandang dimana 1 bangunan kandang dihuni oleh banyak ternak namun ternak tersebut diikat, sedangkan kandang koloni adalah 1 bangunan kandang yang diisi banyak ternak dan ternak tersebut tanpa diikat. Kandang yang baik terbuat dari kayu, beratap seng, berlantai semen dan menghadap arah matahari terbit ( Simamora et al., 2015).

\section{Pemerahan}

Sistem pemerahan yang dilakukan umumnya masih bersifat tradisional, yaitu pemerahan susu dilakukan secara manual menggunakan tangan. Sebelum dilakukan pemerahan pada sapi perah peternak sebelumnya melakukan sanitasi terhadap sapi perah yaitu sanitasi kandang, ternak dan peralatan. Pemerahan umumnya dilakukan dua kali sehari yaitu pemerahan pagi dilakukan pukul 05.00 sampai $06.00 \mathrm{WIB}$, sedangkan pemerahan sore dilakukan mulai pukul 15.00-16.00 WIB. Pasca pemerahan susu peternak hanya membersihkan bagian puting susu menggunakan air hangat setelah pemerahan selesai tanpa mencelupkan tiap puting susu ke dalam larutan desinfektan untuk mencegah terjadinya mastitis.

\section{Simpulan}

Analisis rata-rata usaha BEP di Kabupaten Semarang berdasarkan penerimaan sebesar Rp 31.916/hari dan berdasarkan jumlah produksi sebesar 10,57 liter/hari. Penerimaan rata-rata volume produksi/hari sebesar 24,88 liter/hari dan penerimaan rata-rata Rp 70.771/hari. Dengan demikian maka usaha sapi perah sudah beroperasi di atas Break Even Point. Pemeliharaan sapi perah terdiri dari pemberian pakan (hijauan dan konsentrat) serta minum secara adlibitum, sanitasi ternak dilakukan dua kali sehari, calving internal 12 bulan, tipe kandang adalah konvensional dan pemerahan sapi dilakukan dua kali sehari yaitu pagi dan sore hari.

\section{Pustaka}

Anidyasari, D., A. Setiadi dan Mukson. 2019. Analisis Hubungan Faktor - Faktor Yang Mempengaruhi Pendapatan Peternak Sapi Perah Pada Koperasi Susu Di Kabupaten Semarang. Jurnal Peternakan Lingkungan Tropis. 2 (1). 23-30.

Anggraeni, A dan E. Mariana. 2016. Evaluasi Aspek Teknis Pemeliharaan Sapi Perah Menuju Good Dairy Farming Practices pada Peternakan Sapi Perah Rakyat Pondok Ranggon. Agripet. $16(2)$ : 90-96. 
Dinas Peternakan dan Kesehatan Hewan Provinsi Jawa Tengah. 2014. Data Statistik Peternakan Provinsi Jawa Tengah.

Emawati, S. 2007. Analisis Break Even Point (BEP) Usahatani Pembibitan SapiPotong di Kabupaten Sleman. Sains Peternakan. 5 (2) : 6 -11.

Ernawan, M., E. Trijana dan R. Ghozali. 2016. Analisis Pendapatan Usaha Peternakan Sapi Perah Laktasi (Studi Kasus Di Desa Minggirsari Kecamatan Kanigoro Kabupaten Blitar). AVES: 10 (2) : 25-40.

Haloho, R. D., S. I. Santoso, S. Marzuki., W. Roessali dan A. Setiadi. 2013. Profit function analysis of dairy cattle farming in getasan and west ungaran districts, semarang regency. Journal of the Indonesian Tropical Animal Agriculture. 38 (2) : 116-122.

Haloho, R. D. 2018. Analisis Return On Investment pada Usaha Peternakan Sapi Perah Pt. Sari Indah Kecamatan Pekalongan Barat Kota Pekalongan. 2 (1) : 150-157.

Hertanto S B, Widiati R, Adiarto. 2012. Analisis ekonomi peternakan sapi perah rakyat dan strategi pengembangannya di dataran rendah. Buletin Peternakan. 36(2): 129-140

Londa, P.K., P.O. Waleleng., R.A.J.Legrans dan F,H, Elly. 2017. Analisis Break Even Point (Bep) Usaha Ternak Sapi Perah "Tarekat Msc" Di Kelurahan Pinaras Kota Tomohon. Jurnal Zootek. 32 (1) : 158-166

Santosa, S.I., A. Setiadi dan R. Wulandari. 2013. Analisis Potensi Pengembangan Usaha Peternakan Sapi Perah Dengan Menggunakan Paradigma Agribisnis Di Kecamatan Musuk Kabupaten Boyolali. Buletin Peternakan. 37 (2) : 125-135.

Soekardono. 2009. Ekonomi Agribisnis Peternakan Teori dan Aplikasinya, Akademika Pressindo, Jakarta.

Simamora, T., A.M. Fuah., A.Atabany dan Burhanuddin 2015. Evaluasi Aspek Teknis Peternakan Sapi Perah Rakyat di Kabupaten Karo Sumatera Utara. Jurnal Ilmu Produksi dan Teknologi Hasil Peternakan 3 (1) : 52-58.

Sudono, A., R.F. Rosdiana, dan B.S Setiawan. 2003. Beternak Sapi Perah Secara Intensif. Agromedia Pustaka, Bogor

Sunarto. 2007. Sapiku Penghasil Susu. PT. Sinergi Pustaka Indonesia, Jakarta. 